\title{
Sparassis crispa suppresses mast cell-mediated allergic inflammation: Role of calcium, mitogen-activated protein kinase and nuclear factor- $\kappa B$
}

\author{
HUI-HUN KIM ${ }^{1}$, SOYOUNG LEE ${ }^{1}$, THOUDAM S.K. SINGH ${ }^{1}$, JIN KYEONG CHOI ${ }^{1}$, \\ TAE-YONG SHIN ${ }^{2}$ and SANG-HYUN KIM ${ }^{1}$ \\ ${ }^{1}$ Department of Pharmacology, School of Medicine, Kyungpook National University, Daegu 700-422; \\ ${ }^{2}$ College of Pharmacy, Woosuk University, Jeonju 565-701, Republic of Korea
}

Received February 21, 2012; Accepted April 17, 2012

DOI: $10.3892 /$ ijmm.2012.1000

\begin{abstract}
Allergic inflammatory disease such as food allergy, asthma and atopic dermatitis are increasing worldwide. In this study, we investigated the effect of water extract of Sparassis crispa (WESC) Fr. (Aphyllophoromycetideae) on mast cellmediated allergic inflammation and the possible mechanisms of action. WESC inhibited compound 48/80-induced systemic anaphylaxis and serum histamine release in mice. WESC decreased immunoglobulin $\mathrm{E}$ ( $\mathrm{IgE}$ )-mediated passive cutaneous anaphylaxis. Additionally, WESC reduced histamine release and intracellular calcium in human mast cells activated by phorbol 12-myristate 13-acetate (PMA) and calcium ionophore A23187. WESC decreased PMA and A23187-stimulated expression of pro-inflammatory cytokines, such as tumor necrosis factor (TNF)- $\alpha$, inlerleukin (IL)-6 and IL-1 $\beta$. The inhibitory effect of WESC on pro-inflammatory cytokines was nuclear factor- $\kappa \mathrm{B}$, extracellular signal-regulated kinase and p38 mitogen-activated protein kinase-dependent. Our results suggest potential therapeutic application of WESC in allergic inflammatory diseases.
\end{abstract}

\section{Introduction}

Mushrooms are good food materials whose immunomodulatory potential has been investigated. Sparassis crispa (Wulf.) Fr. (Aphyllophoromycetideae) is an edible mushroom used for a natural medicine that recently became cultivatable in Korea

Correspondence to: Dr Sang-Hyun Kim, Department of Pharmacology, School of Medicine, Kyungpook National University, Daegu 700-422, Republic of Korea

E-mail: shkim72@knu.ac.kr

Dr Tae-Yong Shin, College of Pharmacy, Woosuk University, Jeonju 565-701, Republic of Korea

E-mail: tyshin@woosuk.ac.kr

Key words: Sparassis crispa, allergic inflammation, histamine, calcium, nuclear factor- $\mathrm{\kappa} B$, mast cells and Japan (1). Recently, S. crispa has been reported to have many biological effects such as antitumor, anti-angiogenic, anti-metastatic, and wound healing (1-3). The major component of $S$. crispa is $\beta$-D-glucan, a polysaccharide of D-glucose comprising a $\beta$ - $(1 \rightarrow 3)-D$-glucan backbone $(3,4)$. According to previous research, the $\beta$-glucan content of $S$. crispa was confirmed to be immense, up to $43.6 \%$ of the dry weight (4). S. crispa derived $\beta$-glucan has been known for several beneficial effects, however its allergic responses have not been clarified.

Mast cells are broadly distributed throughout mammalian tissues and play various functions as regulators of allergic inflammation, such as asthma, atopic dermatitis, eczema, and sinusitis. Mast cells have been considered not only in the association of immediate type hypersensitivity but also in late reaction, like inflammatory responses $(5,6)$. Immediate type hypersensitivity is mediated by histamine released in response to the antigen cross-linking of immunoglobulin $\mathrm{E}$ ( $\mathrm{IgE}$ ) bound to FceRI on the mast cells (7). After activation of mast cells, the process of degranulation is triggered which results in the releasing of mediators, such as products of arachidonic acid metabolism, cytokines, proteases and histamine $(8,9)$. In mast cell-mediated inflammatory responses, histamine is one of the most characterized and important mediators implicated in the acute phase of immediate hypersensitivity $(10,11)$. Mast cell activation is initiated by phosphorylation of tyrosine kinase which leads to activation of protein kinase $\mathrm{C}$, mitogen-activated protein kinases (MAPKs), nuclear factor (NF)- $\mathrm{BB}$, and expression of proinflammatory cytokines $(8,12)$.

In the present study, we investigated the effect of the water extract of S. crispa (WESC) on the systemic and local allergic reaction and histamine release from mast cells. The intracellular calcium content was investigated to clarify the mechanism by which WESC inhibited histamine release from mast cells. In addition, the effect of WESC on phorbol 12-myristate 13-acetate (PMA) and calcium ionophore A23187 (PMACI)-induced gene expression and production of proinflammatory cytokines, and the role of NF- $\kappa \mathrm{B}$ and MAPKs in this effect were investigated using human mast cells (HMC-1). In order to determine the amount of active compounds of WESC, we confirmed the contents of $\beta$-glucan in WESC. 


\section{Materials and methods}

Animals. The original stock of male imprinting control region (ICR) mice (6 weeks) and male Sprague-Dawley rats (8 weeks) were purchased from the Dae-Han Experimental Animal Center (Daejeon, Korea). The animals were housed 5 per cage in a laminar air flow room maintained under a temperature of $22 \pm 2^{\circ} \mathrm{C}$ and relative humidity of $55 \pm 5^{\circ} \mathrm{C}$ throughout the study. The care and treatment of the mice were in accordance with the guidelines established by the Public Health Service Policy on the Humane Care and Use of Laboratory Animals and were approved by the Institutional Animal Care and Use Committee.

Reagents and cell culture. Compound 48/80, anti-dinitrophenyl (DNP) IgE, DNP-human serum albumin (HSA), phorbol 12-myristate 13-acetate (PMA), and calcium ionophore A23187 were purchased from Sigma Chemical Co. (St. Louis, MO, USA). The human mast cell line (HMC-1) was grown in Iscove's media (Life Technologies, Grand Island, NY, USA) supplemented with $10 \%$ fetal bovine serum at $37^{\circ} \mathrm{C}$ in $5 \%$ $\mathrm{CO}_{2}$. Passages 4-8 of HMC-1 cells were used throughout the study.

Preparation of WESC. The Sparassis crispa was purchased from the oriental drug store, Bohwa Dang (Jeonbuk, Korea) and identified by D.K. Kim, College of Pharmacy, Woosuk University. A voucher specimen was deposited at the Herbarium of the College of Pharmacy, Woosuk University. The $S$. crispa was ground $(400 \mathrm{x} \mathrm{g,} 30 \mathrm{sec})$ at room temperature using Micro Hammer-Cutter Mill (Culatti Co., Zurich, Switzerland). The particle size was $0.5-2 \mathrm{mM}$ after grinding. The plant sample $(100 \mathrm{x}$ g) was extracted twice with purified water $(500 \mathrm{ml})$ at $70^{\circ} \mathrm{C}$ for $5 \mathrm{~h}$ in a water bath. The extract was passed through filter paper and the filtrate was lyophilized using a $0.45 \mu \mathrm{m}$ syringe filter. The dried extract was dissolved in saline or Tyrode buffer A (HEPES $10 \mathrm{mM}, \mathrm{NaCl} 130 \mathrm{mM}$, $\mathrm{KCl} 5 \mathrm{mM}, \mathrm{CaCl}_{2} 1.4 \mathrm{mM}, \mathrm{MgCl}_{2} 1 \mathrm{mM}$, glucose $1.4 \mathrm{mM}$, $0.1 \%$ bovine serum albumin) before use.

Compound 48/80-induced systemic anaphylaxis. Mice were given an intraperitoneal injection of $8 \mathrm{mg} / \mathrm{kg}$ body weight (BW) of the mast cell degranulator compound 48/80. WESC was administered intraperitoneally at doses of $10-1,000 \mathrm{mg} / \mathrm{kg}$ BW $1 \mathrm{~h}$ before the injection of compound 48/80 ( $\mathrm{n}=10 /$ group). Mortality was monitored for $1 \mathrm{~h}$ after induction of anaphylactic shock. After the mortality test, blood was obtained from the heart of each mouse to measure serum histamine contents.

Passive cutaneous anaphylaxis (PCA). An IgE-dependent cutaneous reaction was carried out as described previously (13). Briefly, mice were injected intradermally with $0.5 \mu \mathrm{g}$ of anti-DNP IgE. After $48 \mathrm{~h}$, each mouse ( $\mathrm{n}=10 /$ group) received an injection of $1 \mu \mathrm{g}$ of DNP-HSA containing $4 \%$ Evans blue (1:4) via the tail vein. Thirty minutes after the challenge, the mice were sacrificed and the dorsal skin (diameter, $1 \mathrm{~cm}$ ) was removed for measurement of the pigmented area.

Preparation of serum and histamine determination. Preparation of serum and determination of histamine contents were examined as previously described (14). Briefly, serum was withdrawn and the histamine contents were measured by the $o$-phthaldialdehyde spectrofluorometric procedure. The fluorescent intensity was measured at emission $438 \mathrm{~nm}$ and excitation $353 \mathrm{~nm}$ using a spectrofluorometer.

Determination of intracellular calcium. The intracellular calcium was measured with the use of the fluorescence indicator Fluo-3/AM (Molecular Probes, Eugene, OR, USA). HMC-1 cells were pre-incubated with Fluo-3/AM for $30 \mathrm{~min}$ at $37^{\circ} \mathrm{C}$. After washing the dye from the cell surface, the cells were treated with WESC for $10 \mathrm{~min}$ before adding PMACI. It was excited at $488 \mathrm{~nm}$, and the emission was filtered with $515 \mathrm{~nm}$ by flow cytometer (BD Biosciences Pharmingen, San Diego, CA, USA) and visualized by a fluorescence microscope Olympus BX51 (Olympus, Center Valley, PA, USA).

RNA extraction and $m R N A$ detection. The total cellular RNA was isolated from the cells (1x10\%/well in a 24-well plate) after stimulation with PMA $(20 \mathrm{nM})$ and A23187 $(1 \mu \mathrm{M})$ with or without WESC for $2 \mathrm{~h}$ using TRI reagent (Molecular Research Center, Cincinnati, OH, USA) according to the manufacturer's protocol. The first strand complementary DNA (cDNA) was synthesized using the Superscript II reverse-transcriptase (Invitrogen, Carlsbad, CA, USA). A reverse transcriptase polymerase chain reaction (RT-PCR) was used to analyze the expression of mRNA for TNF- $\alpha$, IL- 6 , and $\beta$-actin (internal control). The conditions for the reverse transcription and PCR steps were similar to those described previously (13). The amplified products were separated by electrophoresis on a $2 \%$ agarose gel containing ethidium bromide, documented using a Kodak DC 290 digital camera and digitized with UN-SCAN-IT software (Silk Scientific, Inc., Orem, UT, USA). The band intensity was normalized to that of $\beta$-actin in the same sample.

Enzyme-linked immunosorbent assay (ELISA). The secretion of TNF- $\alpha$ and IL- 6 was measured by the modification of an enzyme-linked immunosorbent assay (ELISA) as previously described (15). HMC-1 cells were cultured with media and resuspended in Tyrode buffer A. The cells were sensitized with PMACI for $8 \mathrm{~h}$ in the absence or presence of WESC. ELISA was performed by coating 96-well plates with $6.25 \mathrm{ng} /$ well of monoclonal antibody with specificity for TNF- $\alpha$ and IL-6, respectively.

Western blot analysis. HMC-1 cells were washed 3 times with PBS and resuspended in lysis buffer. Samples were electrophoresed using $12 \%$ sodium dodecyl sulfate-polyacrylamide gel electrophoresis, as described elsewhere (16), and then transferred to a nitrocellulose membrane. The nucleus and cytosolic p65 NF- $\kappa \mathrm{B}$ and $\mathrm{I} \kappa \mathrm{B} \alpha$ was assayed using anti-NF- $\kappa \mathrm{B}$ (p65) and anti-I $\kappa \mathrm{B} \alpha$ antibody (Santa Cruz Biotechnology, Inc., Santa Cruz, CA, USA). The phosphorylation of ERK and p38 was determined using anti-phospho-p38 and anti-phosphoERK antibodies (Cell Signaling Technology, Inc., Beverly, MA, USA). Immunodetection was performed the using Supersignal West Pico chemiluminescent substrate (Thermo Fisher Scientific, Waltham, MA, USA).

Transient transfection and luciferase activity assay. For transient transfection, HMC- 1 cells were seeded at $2 \times 10^{6}$ 
Table I. Effect of WESC on compound 48/80-induced systemic anaphylaxis.

\begin{tabular}{lcc}
\hline $\begin{array}{l}\text { WESC treatment } \\
(\mathrm{mg} / \mathrm{kg}, \mathrm{BW})\end{array}$ & $\begin{array}{c}\text { Compound 48/80 } \\
(8 \mathrm{mg} / \mathrm{kg}, \mathrm{BW})\end{array}$ & $\begin{array}{c}\text { Mortality } \\
(\%)\end{array}$ \\
\hline None (saline) & + & 100 \\
10 & + & 100 \\
100 & + & 70 \\
500 & + & 20 \\
1000 & + & 0 \\
1000 & - & 0 \\
\hline
\end{tabular}

Groups of mice ( $n=10$ /group) were intraperitoneally pretreated with $200 \mu \mathrm{l}$ of saline or WESC at various doses $1 \mathrm{~h}$ before the intraperitoneal injection of compound 48/80. Mortality (\%) within $1 \mathrm{~h}$ following compound $48 / 80$ injection is represented as the number of dead mice $\mathrm{x} 100 /$ total number of experimental mice.

in a 6-well plate 1 day before transient transfection. The expression vectors containing the $\mathrm{NF}-\kappa \mathrm{B}$ luciferase reporter construct (pNF- $\mathrm{kB}-\mathrm{LUC}$, plasmid containing NF- $\mathrm{\kappa B}$ binding site; Stantagen, Grand Island, NY, USA) were transfected with serum- and antibiotics-free Iscove's medium containing $8 \mu 1$ Lipofectamine 2000 reagent (Invitrogen). After $5 \mathrm{~h}$ of incubation, the medium was replaced with Iscove's medium containing 10\% FBS and antibiotics. Cells were allowed to recover at $37^{\circ} \mathrm{C}$ for $30 \mathrm{~h}$ and subsequently were stimulated as indicated. Cell lysates were prepared and assayed for luciferase activity using the Luciferase Assay System (Promega, Madison, WI, USA), according to the manufacturer's instructions.

Measurement of $\beta$-glucan in WESC. $\beta$-glucan contents in WESC were determined using a mushroom $\beta$-glucan assay kit (K-YBGL; Megazyme International, Wicklow, Ireland) according to the manufacturer's protocol. The lyophilized extract of S. crispa $(100 \mathrm{mg})$ and $1.5 \mathrm{ml}$ of $37 \%$ hydrochloric $\operatorname{acid}(\mathrm{v} / \mathrm{v}, 10 \mathrm{~N})$ were mixed vigorously, and incubated at $30^{\circ} \mathrm{C}$ for $45 \mathrm{~min}$. The materials were mixed with $10 \mathrm{ml}$ distilled water and incubated at $100^{\circ} \mathrm{C}$ for $2 \mathrm{~h}$. After centrifugation at $1,500 \mathrm{x} \mathrm{g}$ for $10 \mathrm{~min}, 0.1 \mathrm{ml}$ aliquots were combined with $0.1 \mathrm{ml}$ of a mixture of exo-(1-3)- $\beta$-glucanase $(20 \mathrm{U} / \mathrm{ml})$ plus $\beta$-glucosidase $(4 \mathrm{U} / \mathrm{ml})$ in $200 \mathrm{mM}$ sodium acetate buffer (pH 5.0) and incubated at $40^{\circ} \mathrm{C}$ for $60 \mathrm{~min}$. To measure total glucan content, $3 \mathrm{ml}$ of glucose oxidase/peroxidase mixture (GOPOD) was added and incubated at $40^{\circ} \mathrm{C}$ for $20 \mathrm{~min}$. The absorbance of samples was analyzed spectrophotometrically at $510 \mathrm{~nm}$ against the reagent blank using a spectrophotometer (Shimadzu, UV-1201). To measure the $\alpha$-glucan content, $2 \mathrm{ml}$ of $2 \mathrm{M} \mathrm{KOH}$ was added, and the phytoglycogen and starch were dissolved by stirring for $20 \mathrm{~min}$ in an ice water bath. The suspension was added to $8 \mathrm{ml}$ of $1.2 \mathrm{M}$ sodium acetate buffer ( $\mathrm{pH} 3.8$ ), mixed with $0.2 \mathrm{ml}$ of amyloglucosidase $(16,300 \mathrm{U} / \mathrm{ml})$ plus invertase $(500 \mathrm{U} / \mathrm{ml})$, and incubated in a water bath for $30 \mathrm{~min}$ at $40^{\circ} \mathrm{C}$ with intermittent mixing on a vortex stirrer. Tubes were centrifuged (10 min, 1,500 x g), and $0.1 \mathrm{ml}$ aliquots were combined with $0.1 \mathrm{ml}$ of sodium acetate
Table II. Time-dependent effects of WESC on compound 48/80-induced systemic anaphylaxis.

\begin{tabular}{lccc}
\hline $\begin{array}{l}\text { WESC treatment } \\
(\mathrm{mg} / \mathrm{kg}, \mathrm{BW})\end{array}$ & $\begin{array}{c}\text { Compound 48/80 } \\
(8 \mathrm{mg} / \mathrm{kg}, \mathrm{BW})\end{array}$ & $\begin{array}{c}\text { Time } \\
(\mathrm{min})\end{array}$ & $\begin{array}{c}\text { Mortality } \\
(\%)\end{array}$ \\
\hline None (saline) & + & & 100 \\
1000 & + & 0 & 0 \\
1000 & + & 5 & 0 \\
1000 & + & 10 & 30 \\
1000 & + & 15 & 50 \\
1000 & + & 20 & 100 \\
\hline
\end{tabular}

Mice ( $n=10$ /group) were intraperitoneally pretreated with $200 \mu \mathrm{l}$ of saline or WESC. WESC $(1000 \mathrm{mg} / \mathrm{kg})$ was given 5, 10, 15 and $20 \mathrm{~min}$ after the intraperitoneal injection of compound 48/80. Mortality (\%) with in $1 \mathrm{~h}$ following compound 48/80 injection is represented as the number of dead mice x 100/total number of experimental mice.

buffer (200 mM, pH 5.0) plus $3 \mathrm{ml}$ of GOPOD reagent and incubated for at $40^{\circ} \mathrm{C}$ for $30 \mathrm{~min}$. The absorbance of samples was analyzed at $510 \mathrm{~nm}$. The $\beta$-glucan content was determined by subtracting the $\alpha$-glucan from the total glucan content.

Statistical analysis. Statistical analyses were performed using SAS statistical software (SAS Institute, Inc., Cary, NC, USA). Treatment effects were analyzed using analysis of variance, followed by Duncan's multiple range tests. $\mathrm{P}<0.05$ indicated significance.

\section{Results}

Effect of WESC on systemic and local anaphylaxis. To determine the effect of WESC in allergic reaction, an in vivo model of a systemic anaphylaxis was used. Compound $48 / 80$ $(8 \mathrm{mg} / \mathrm{kg})$ was used as a model of induction for a systemic fatal allergic reaction. After the intraperitoneal injection of compound 48/80, the mice were monitored for $1 \mathrm{~h}$, after which the mortality rate was determined. Injection of compound $48 / 80$ into mice induced fatal shock in $100 \%$ of the animals. When WESC was intraperitoneally pretreated at doses ranging from 10 to $1,000 \mathrm{mg} / \mathrm{kg}$ for $1 \mathrm{~h}$, the mortality was dose-dependently reduced. WESC completely inhibited compound 48/80-induced fatal shock at $1,000 \mathrm{mg} / \mathrm{kg}$ (Table I). In addition, the mortality of mice administered with WESC $(1,000 \mathrm{mg} / \mathrm{kg}) 5,10,15$ and $20 \mathrm{~min}$ after compound 48/80 injection time-dependently increased (Table II).

The effect of WESC on the compound 48/80-induced serum histamine release was investigated. The histamine level caused by compound $48 / 80$ was decreased by WESC in a dose-dependent manner (Fig. 1A). To confirm the anti-allergic effects of WESC, we used a passive cutaneous anaphylaxis (PCA) model induced by anti-DNP-IgE and DNP-HSA. To compare to amount of dye with control, the left dorsal skin of these mice was injected with saline alone. WESC was intraperitoneally administered $1 \mathrm{~h}$ prior to the challenge with antigen. WESC dose-dependently inhibited PCA reaction (Fig. 1B). 


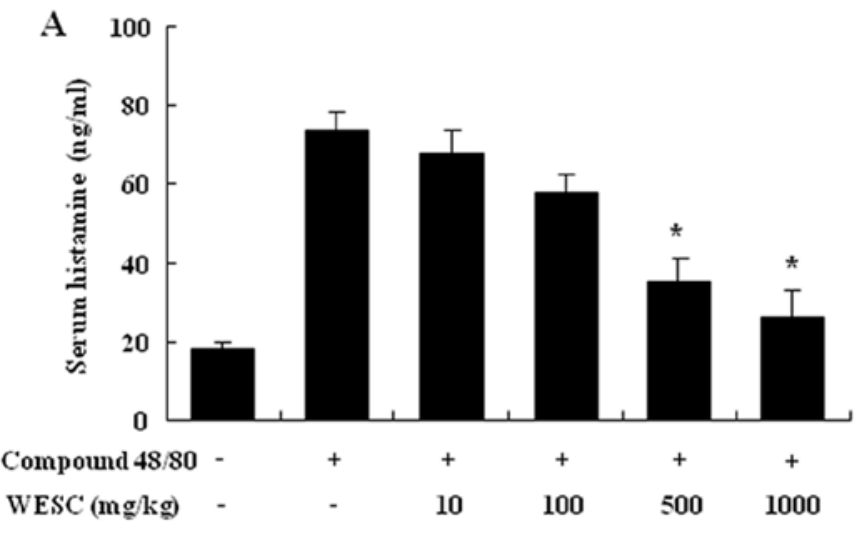

B

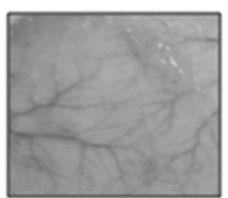

Control

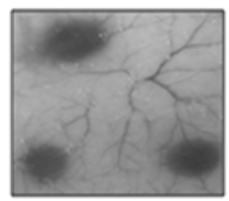

Saline

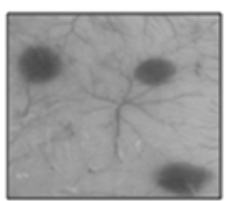

WESC (1000 mg/kg)

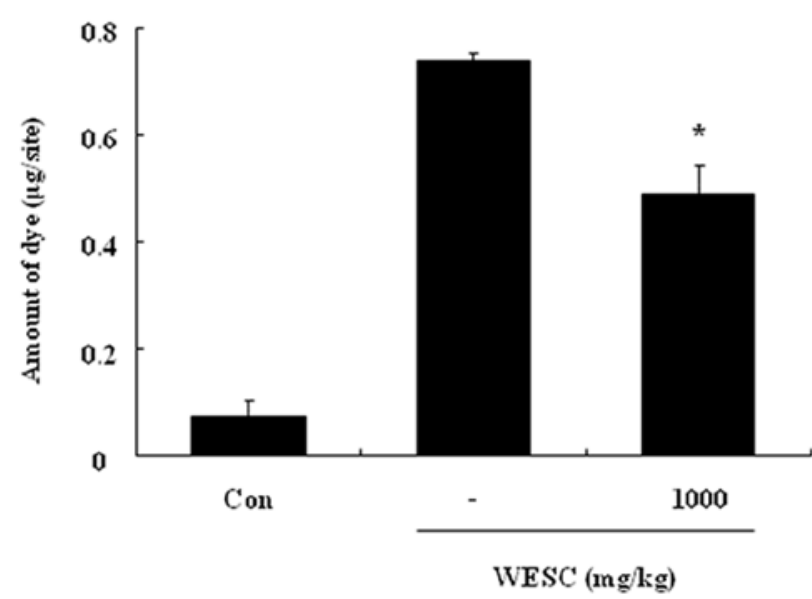

Figure 1. Effects of WESC on serum histamine and PCA reactions. (A) Groups of mice ( $n=10 /$ group) were intraperitoneally pretreated with $200 \mu 1$ of saline or WESC. WESC was given at various doses $1 \mathrm{~h}$ before the injection of compound $48 / 80$. The compound $48 / 80$ was given intraperitoneally to the group of mice. The blood was obtained from the heart of each mouse and histamine content was measured by a spectrofluorometer. (B) WESC was intraperitoneally administered $1 \mathrm{~h}$ prior to the challenge with antigen. Each amount of dye extracted as described in Materials and methods and measured by spectrophotometry. Each bar represents the mean \pm SEM of three independent experiments. "Significant difference at $\mathrm{P}<0.05$.

Effect of WESC on histamine release and intracellular calcium. We estimated the reducing effects of WESC on the histamine release from PMACI-induced HMC-1 cells. Mast cells released a high level of histamine when simulated with PMACI (Fig. 2A). When WESC was pretreated for $30 \mathrm{~min}$, histamine was dose-dependently inhibited in PMACI-induced HMC-1. Up to $1 \mathrm{mg} / \mathrm{ml}$ of WESC did not show cytotoxicity (data not shown). To investigate the mechanism responsible for the reduction of histamine after WESC treatment, we assayed the intracellular calcium levels. Calcium movements across membranes of mast cells are critical to histamine release (17). When HMC-1 cells were stimulated with PMACI, intracellular calcium levels were significantly elevated (Fig. 2B). WESC $(100 \mu \mathrm{g} / \mathrm{ml})$ decreased the intracellular calcium level.

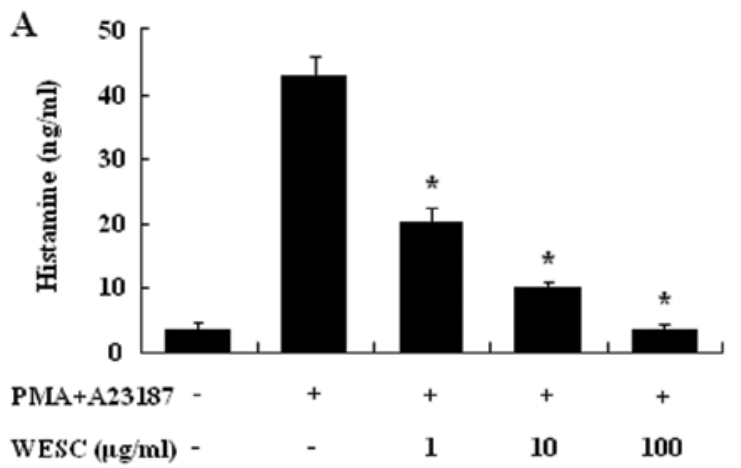

B

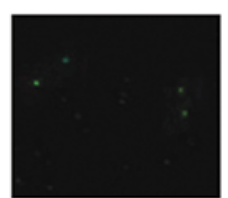

Control

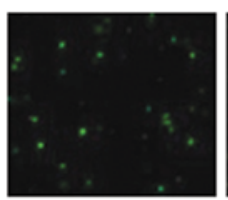

PMLACI

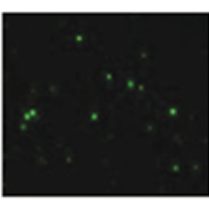

PMACI+WESC

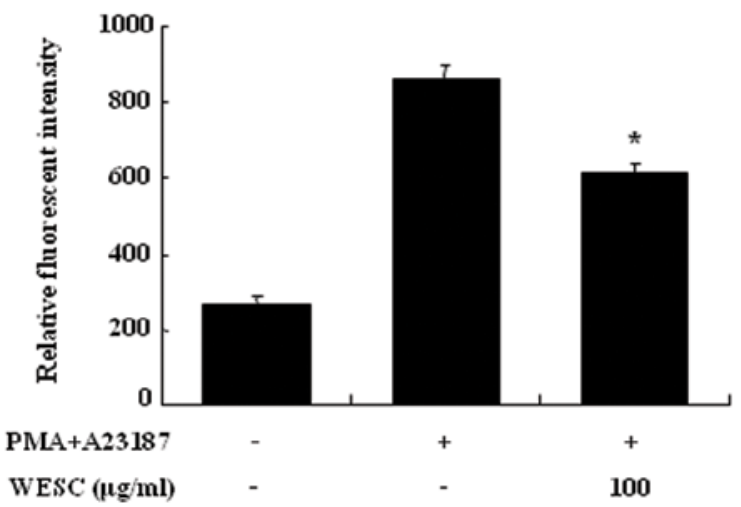

Figure 2. Effects of WESC on histamine release and intracellular calcium in mast cells. HMC-1 cells $\left(1 \times 10^{6}\right.$ cells $\left./ \mathrm{ml}\right)$ were pre-incubated with WESC for $30 \mathrm{~min}$ prior to incubation with PMA (20 nM) and calcium ionophore A23187 $(1 \mu \mathrm{M})$. (A) Histamine content was measured by a spectrofluorometer. (B) Intracellular calcium was detected by a fluorescence microscope and flow cytometer. Each bar represents the mean \pm SEM of three independent experiments. "Significant difference from PMACI value at $\mathrm{P}<0.05$.

The levels of intracellular calcium were also assessed by the relative fluorescent intensity.

Effect of WESC on the expression and secretion of proinflammatory cytokines. We investigated the inhibitory effect of WESC on the expression of proinflammatory cytokines such as TNF- $\alpha$ and IL-6. The HMC- 1 cell line is a useful tool for researching the cytokine activation pathway $(18,19)$. Previously we reported that gene expression of TNF- $\alpha$ and IL-6 peaked $4 \mathrm{~h}$ after treatment of PMACI (20). Consequently, HMC- 1 cells were stimulated by PMACI during $4 \mathrm{~h}$, and the cells were preincubated with WESC for $30 \mathrm{~min}$. Fig. 3A shows that the expression of proinflammatory cytokines was inhibited by WESC. To confirm the correlation of mRNA expression with protein production, we measured the secretion of TNF- $\alpha$ and IL- 6 . When HMC- 1 cells were stimulated with PMACI for $8 \mathrm{~h}$, the secretion of cytokines was remarkably induced. WESC dose-dependently inhibited the secretion of TNF- $\alpha$ and IL- 6 in PMACI-stimulated HMC-1 cells (Fig. 3B). 


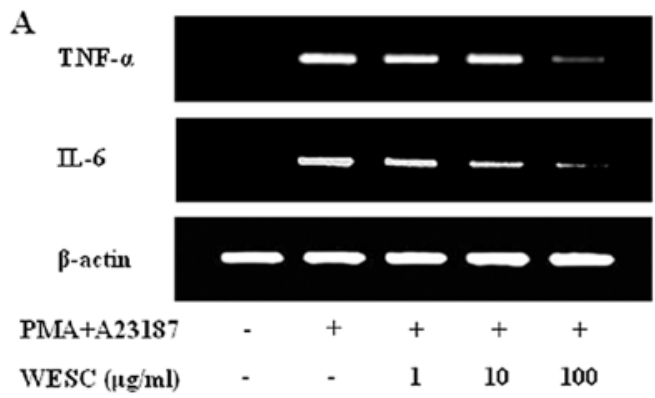

B
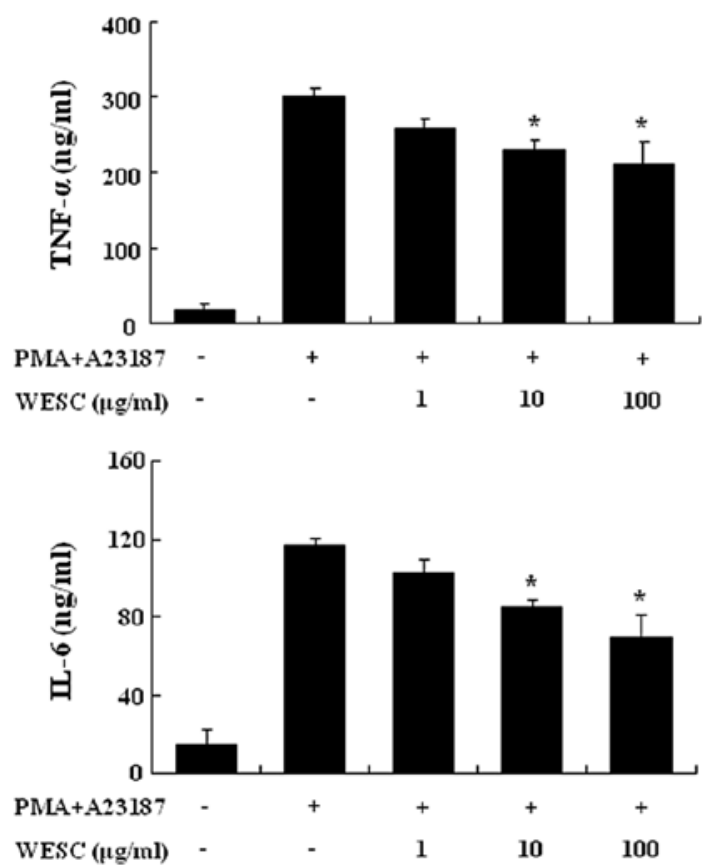

Figure 3. Effects of WESC on the gene expression and secretion of proinflammatory cytokines in mast cells. HMC-1 were treated with WESC for $30 \mathrm{~min}$ before being stimulated with PMA $(20 \mathrm{nM})$ and ionophore A23187 $(1 \mu \mathrm{M})$. (A) Extraction and analysis of mRNA was performed as described in Materials and methods. The gene expression of TNF- $\alpha$ and IL-6 were determined by RT-PCR. (B) The level of TNF- $\alpha$ and IL- 6 in supernatant was measured using ELISA and represented as the mean \pm SEM of three independent experiments. "Significant difference from the PMACI value at $\mathrm{P}<0.05$.

Effect of WESC on the activation of NF- $\kappa B$ and MAPKs. To investigate the intracellular mechanism responsible for the inhibitory effect of WESC on the expression of proinflammatory cytokines, we examined the effect of WESC on the activation of transcription factors, NF- $\mathrm{KB}$ and MAPKs. NF- $\mathrm{\kappa B}$ is an important transcriptional regulator of inflammatory cytokines and plays a crucial role in immune and inflammatory responses. Stimulation of HMC-1 with PMACI induced the nuclear translocation of $\mathrm{p} 65 \mathrm{NF}-\kappa \mathrm{B}$ and degradation of I $\mathrm{B} \alpha$ after $2 \mathrm{~h}$ of incubation. WESC inhibited the PMACIinduced nuclear translocation of NF- $\mathrm{KB}$ and degradation of I $\kappa \mathrm{B} \alpha$ (Fig. 4A). To confirm the inhibitory effect of WESC on the NF- $\mathrm{KB}$ activation, we examined the effect of WESC on the $\mathrm{NF}-\kappa \mathrm{B}-$ dependent gene reporter assay. HMC-1 cells were transiently transfected with a NF-kB-luciferase reporter construct or an empty vector. Exposure of cells to PMACI increased the luciferase activity in the cells transfected with the NF- $\mathrm{kB}$ -

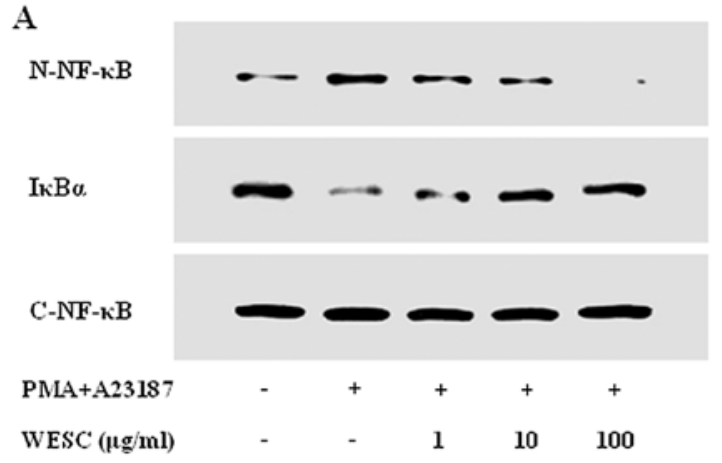

B

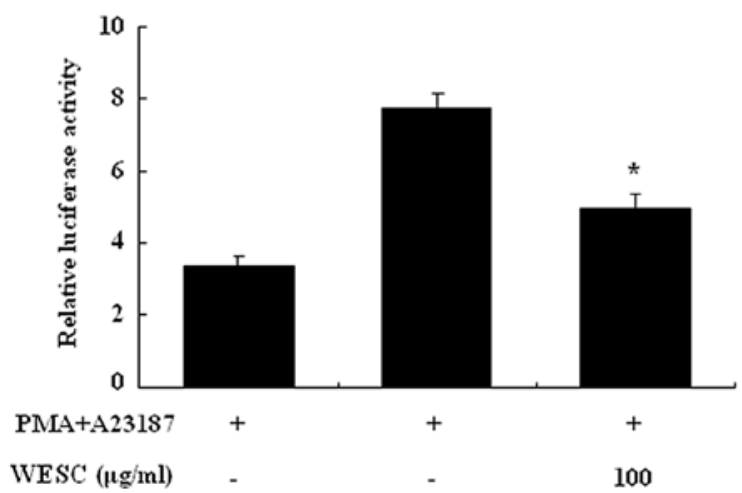

Figure 4. Effects of WESC on the activation of NF- $\mathrm{BB}$ in mast cells. HMC-1 were pretreated with WESC for 30 min prior to PMA $(20 \mathrm{nM})$ and A23187 $(1 \mu \mathrm{M})$ stimulation for $2 \mathrm{~h}$. (A) Nuclear translocation of NF- $\kappa \mathrm{B}$ and $\mathrm{I} \kappa \mathrm{B} \alpha \mathrm{deg}-$ radation were assayed by western blot analysis $(\mathrm{N}-\mathrm{NF}-\kappa \mathrm{B}$, nuclear $\mathrm{NF}-\kappa \mathrm{B}$; C-NF- $\kappa$ B, cytoplasmic NF- $\mathrm{B}$ ). (B) Cells were transiently transfected with the $N F-\kappa B$-luciferase reporter construct or empty vector. Then, the cells were incubated with PMA and A23187 with or without WESC. NF- $\kappa$ B-dependent transcriptional activity was determined by the luciferase activity assay. Each bar represents the mean \pm SEM of three independent experiments. *Significant difference from the PMACI value at $\mathrm{P}<0.05$.

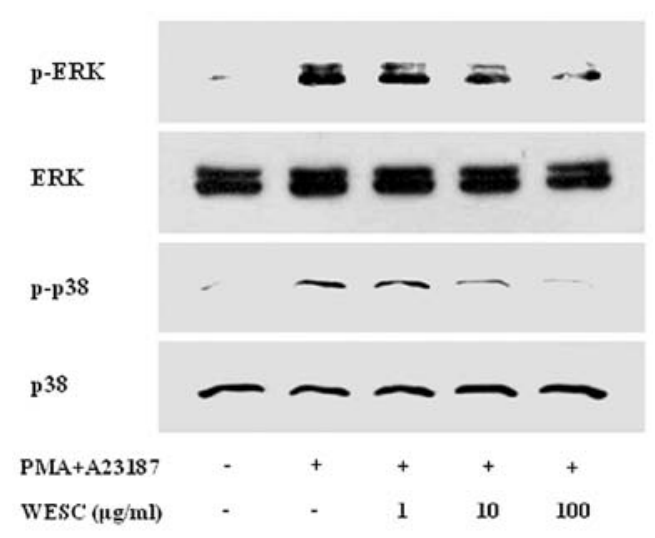

Figure 5. Effect of WESC on phosphorylation of MAPKs in mast cells. HMC-1 were pretreated with WESC for 30 min prior to PMA $(20 \mathrm{nM})$ and A23187 $(1 \mu \mathrm{M})$ stimulation for $30 \mathrm{~min}$, and phosphorylation of $\mathrm{p} 38$ and ERK was assayed by western blot analysis.

luciferase reporter construct (Fig. 4B). WESC significantly reduced PMACI-induced luciferase activity.

The MAPK signaling cascades also regulate important cellular processes including gene expression, cell proliferation, and cell survival and death (21). Previously we documented 
that PMACI activates all three types of MAPKs such as p38, JNK, and ERK at 15-30 min in HMC-1 (22). In the present results, stimulation of cells with PMACI induced phosphorylation of p38, JNK, and ERK, and WESC markedly attenuated PMACI-induced phosphorylation of ERK and p38 MAPK (Fig. 5). However WESC did not affect the phosphorylation of JNK (data not shown).

\section{Discussion}

Anaphylaxis is a life-threatening syndrome induced by a sudden systemic release of inflammatory mediators, such as histamine, various cytokines and lipid-derived mediators (23). Using in vitro and in vivo models, we showed that WESC has anti-allergic properties. WESC inhibited compound 48/80induced systemic allergic reaction (anaphylaxis) and serum histamine release in mice. These results indicate that mast cellmediated immediate-type allergic reactions are inhibited by WESC. In addition, WESC-administered mice were protected from IgE-mediated PCA, which is one of the most important in vivo models of anaphylaxis in a local allergic reaction. This finding suggests that WESC might be useful in the treatment of allergic disease, particularly skin reactions.

Histamine was originally considered as a mediator of acute inflammatory and immediate hypersensitivity responses. Recently, it has been reported that histamine affects chronic inflammation and regulates several essential events of the immune response, such as immune cell maturation, polarization, and lymphocyte responsiveness (24). Many reports have established that stimulation of mast cells with compound 48/80 or IgE initiates the activation of signal transduction pathways, which lead to histamine release. Several studies have shown that compound 48/80 and other polybasic compound are able, apparently directly, to activate G-proteins (25). Compound $48 / 80$ increases the permeability of the lipid bilayer membrane by causing a perturbation in the membrane. These reports indicate that the increase in membrane permeability may be an essential trigger for the release of the mediator from mast cells. In this sense, anti-allergic agents having a membranestabilizing action may be desirable (26). WESC might stabilize the lipid bilayer membrane, thus preventing the compound 48/80-induced membrane perturbation.

Intracellular calcium plays an important role in the release of histamine and the expression of cytokines. Calcium movements across the membranes of mast cells represent a major target for efficient anti-allergic drugs, as these are essential events linking stimulation to secretion. In our results, WESC decreased the intracellular calcium level in mast cells. We suggest that the decreased intracellular calcium levels may be involved in the inhibitory effect of WESC on histamine release.

The HMC-1 cell line is one of the useful cells for studying cytokine activation pathways (8). The various types of cytokines produced by HMC-1 with PMACI stimulation supports the well-recognized role of mast cells in immediate-type hypersensitivity. TNF- $\alpha$ and IL- 6 , the known proinflammatory cytokines, play an important role in triggering and sustaining the allergic inflammatory response in mast cells $(27,28)$. Mast cells are a principal source of TNF- $\alpha$ in human dermis. TNF- $\alpha$ has major amplifying effect in asthmatic inflammation and potently stimulates airway epithelial cells to produce cytokines (29). It promote inflammation, leukocyte infiltration, chemotaxis of neutrophils and T cells (30). IL-6 is also produced from mast cells, and its local accumulation is associated with PCA reaction (31). These reports indicate that the reduction of proinflammatory cytokines from mast cells is one of the key indicators of reduced allergic symptoms. In the present study, WESC inhibited the expression of TNF- $\alpha$ and IL-6 in PMACIstimulated mast cells. This result suggests that the anti-allergic effect of WESC results from its inhibition of TNF- $\alpha$ and IL-6 generation from mast cells.

Expression of TNF- $\alpha$ and IL- 6 is regulated by the activation of the transcription factor $N F-\kappa B(32)$. NF- $\kappa B$ regulates the expression of multiple inflammatory and immune genes and plays a critical role in chronic inflammatory diseases. Activation of NF- $\kappa \mathrm{B}$ required phosphorylation and proteolytic degradation of the inhibitory protein $\mathrm{I} \kappa \mathrm{B} \alpha$, an endogenous inhibitor that binds to NF- $\kappa \mathrm{B}$ in the cytoplasm. In PMACIstimulated mast cells, WESC decreased the degradation of $\mathrm{I} \kappa \mathrm{B} \alpha$ and nuclear translocation of $\mathrm{NF}-\kappa \mathrm{B}$. The data demonstrated that WESC attenuates activation of $\mathrm{NF}-\kappa \mathrm{B}$ and downstream cytokine expression such as TNF- $\alpha$ and IL-6. To further identify the mechanism of WESC, we evaluated the inhibitory effect of WESC on activation of MAPKs, such as p38, JNK and ERK in PMACI-stimulated mast cells. The MAPK cascade is one of the important signaling pathways in immune responses. The MAPK signaling cascades regulate important cellular processes including gene expression, cell proliferation, cell survival and death, and cell mobility (21). Precise signaling pathways in allergic diseases among three types of MAPKs such as ERK, JNK, and p38 are still unclear. However, the induction of inflammatory cytokine genes requires activation of the p38 MAPK and ERK (33). In our results, WESC decreased phosphorylation of ERK and p38 MAPKs in PMACI-stimulated mast cells. This data suggest that WESC may decrease cytokine production and activation of NF- $\kappa \mathrm{B}$ via inhibition of ERK and p38 MAPK.

In summary, WESC significantly reduced mast cell-mediated allergic inflammation in in vivo and in vitro models. In the present study, we used the whole water extract of S.crispa, not a purified single compound. However $\beta$-glucan is already known to be the major compound of WESC. We examined the $\beta$-glucan content in WESC using a mushroom $\beta$-glucan assay kit. The $\beta$-glucan content in WESC was $39.3 \%$. Therefore, we assume that $\beta$-glucan is responsible for the anti-allergic inflammatory effects of WESC. In conclusion, $S$. crispa could contribute to prevention or treatment of mast cell-mediated allergic inflammatory diseases.

\section{Acknowledgements}

This study was supported by the grant of the Korea Healthcare Technology R\&D Project, Ministry for Health, Welfare and Family Affairs, Republic of Korea (A090015).

\section{References}

1. Yoshikawa K, Kokudo N, Hashimoto T, Yamamoto K, Inose T and Kimura T: Novel phthalide compounds from Sparassis crispa (Hanabiratake), Hanabiratakelide A-C, exhibiting anticancer related activity. Biol Pharm Bull 33: 1355-1359, 2010. 
2. Kwon AH, Qiu Z, Hashimoto M, Yamamoto K and Kimura T: Effects of medicinal mushroom (Sparassis crispa) on wound healing in streptozotocin-induced diabetic rats. Am J Surg 197: 503-509, 2009

3. Yamamoto K, Kimura T, Sugitachi A and Matsuura N: Antiangiogenic and anti-metastatic effects of beta-1,3-D-glucan purified from Hanabiratake, Sparassis crispa. Biol Pharm Bull 32: 259-263, 2009.

4. Tada R, Harada T, Nagi-Miura N, et al: NMR characterization of the structure of a beta-(1-3)-D-glucan isolate from cultured fruit bodies of Sparassis crispa. Carbohydr Res 342: 2611-2618, 2007.

5. Caughey GH: Mast cell proteases as protective and inflammatory mediators. Adv Exp Med Biol 716: 212-234, 2011.

6. Galli SJ, Tsai M and Piliponsky AM: The development of allergic inflammation. Nature 454: 445-454, 2008.

7. Galli SJ, Kalesnikoff J, Grimbaldeston MA, Piliponsky AM, Williams CM and Tsai M: Mast cells as 'tunable' effector and immunoregulatory cells: recent advances. Annu Rev Immunol 23: 749-786, 2005

8. Kim SH, Jun CD, Suk K, et al: Gallic acid inhibits histamine release and pro-inflammatory cytokine production in mast cells. Toxicol Sci 91: 123-131, 2006.

9. Amin K: The role of mast cells in allergic inflammation. Respir Med 106: 9-14, 2012.

10. Lee DH, Kim SH, Eun JS and Shin TY: Mosla dianthera inhibits mast cell-mediated allergic reactions through the inhibition of histamine release and inflammatory cytokine production. Toxicol Appl Pharmacol 216: 479-484, 2006.

11. Tagen M, Elorza A, Kempuraj D, et al: Mitochondrial uncoupling protein 2 inhibits mast cell activation and reduces histamine content. J Immunol 183: 6313-6319, 2009.

12. Gwack Y, Feske S, Srikanth S, Hogan PG and Rao A: Signalling to transcription: store-operated $\mathrm{Ca}^{2+}$ entry and NFAT activation in lymphocytes. Cell Calcium 42: 145-156, 2007.

13. Bae Y, Lee S and Kim SH: Chrysin suppresses mast cell-mediated allergic inflammation: involvement of calcium, caspase-1 and nuclear factor-kappaB. Toxicol Appl Pharmacol 254: 56-64 2011.

14. Kim SH, Lee S, Kim IK, et al: Suppression of mast cell-mediated allergic reaction by Amomum xanthiodes. Food Chem Toxico 45: 2138-2144, 2007

15. Lee S, Yun HS and Kim SH: The comparative effects of mesoporous silica nanoparticles and colloidal silica on inflammation and apoptosis. Biomaterials 32: 9434-9443, 2011.

16. Lee S, Suk K, Kim IK, et al: Signaling pathways of bisphenol A-induced apoptosis in hippocampal neuronal cells: role of calcium-induced reactive oxygen species, mitogen-activated protein kinases, and nuclear factor-kappaB. J Neurosci Res 86 : 2932-2942, 2008.

17. Eisenhut $\mathrm{M}$ and Wallace $\mathrm{H}$ : Ion channels in inflammation. Pflugers Arch 461: 401-421, 2011.
18. Shin TY, Kim SH, Suk K, et al: Anti-allergic effects of Lycopus lucidus on mast cell-mediated allergy model. Toxicol Appl Pharmacol 209: 255-262, 2005.

19. Kim GY, Lee JW, Ryu HC, Wei JD, Seong CM and Kim JH: Proinflammatory cytokine IL-1beta stimulates IL-8 synthesis in mast cells via a leukotriene B4 receptor 2-linked pathway, contributing to angiogenesis. J Immunol 184: 3946-3954, 2010.

20. Park $\mathrm{HH}$, Lee S, Oh JM, et al: Anti-inflammatory activity of fisetin in human mast cells (HMC-1). Pharmacol Res 55: 31-37, 2007.

21. Arbabi S and Maier RV: Mitogen-activated protein kinases. Crit Care Med 30 (Suppl 1): S74-S79, 2002.

22. Kim SH, Choi CH, Kim SY, Eun JS and Shin TY: Anti-allergic effects of Artemisia iwayomogi on mast cell-mediated allergy model. Exp Biol Med (Maywood) 230: 82-88, 2005

23. Boden SR and Wesley Burks A: Anaphylaxis: a history with emphasis on food allergy. Immunol Rev 242: 247-257, 2011.

24. Jutel M, Blaser $\mathrm{K}$ and Akdis CA: Histamine in allergic inflammation and immune modulation. Int Arch Allergy Immunol 137: 82-92, 2005.

25. Palomaki VA and Laitinen JT: The basic secretagogue compound $48 / 80$ activates $G$ proteins indirectly via stimulation of phospholipase D-lysophosphatidic acid receptor axis and 5-HT1A receptors in rat brain sections. Br J Pharmacol 147: 596-606, 2006.

26. Kim SY, Kim SH, Shin HY, et al: Effects of Prunella vulgaris on mast cell-mediated allergic reaction and inflammatory cytokine production. Exp Biol Med (Maywood) 232: 921-926, 2007.

27. Walsh LJ, Trinchieri G, Waldorf HA, Whitaker D and Murphy GF: Human dermal mast cells contain and release tumor necrosis factor alpha, which induces endothelial leukocyte adhesion molecule 1. Proc Natl Acad Sci USA 88: 4220-4224, 1991.

28. Stone KD, Prussin C and Metcalfe DD: IgE, mast cells, basophils, and eosinophils. J Allergy Clin Immunol 125 (Suppl 2): S73-S80, 2010.

29. Galli SJ, Gordon JR and Wershil BK: Cytokine production by mast cells and basophils. Curr Opin Immunol 3: 865-872, 1991.

30. Thomas PS: Tumour necrosis factor-alpha: the role of this multifunctional cytokine in asthma. Immunol Cell Biol 79: 132-140, 2001.

31. Mican JA, Arora N, Burd PR and Metcalfe DD: Passive cutaneous anaphylaxis in mouse skin is associated with local accumulation of interleukin-6 mRNA and immunoreactive interleukin-6 protein. J Allergy Clin Immunol 90: 815-824, 1992.

32. Karin M: NF-kappaB as a critical link between inflammation and cancer. Cold Spring Harb Perspect Biol 1: a000141, 2009.

33. Dong C, Davis RJ and Flavell RA: MAP kinases in the immune response. Annu Rev Immunol 20: 55-72, 2002. 